\title{
Calcium Regulation of Androgen Receptor Expression in the Human Prostate Cancer Cell Line LNCaP*
}

\author{
YUEWEN GONG†, LEEN J. BLOK $\ddagger$, JAIME E. PERRY, JONATHAN K. LINDZEY§, \\ AND DONALD J. TINDALL
}

Departments of Urology and Biochemistry and Molecular Biology, Mayo Foundation, Rochester, Minnesota 55905

\begin{abstract}
Elevation of intracellular calcium levels in the presence of normal androgen levels has been implicated in apoptotic prostate cell death. Since the androgen receptor (AR) plays a critical role in the regulation of growth and differentiation of the prostate, it was of interest to determine whether $\mathrm{Ca}^{2+}$ would affect the expression of androgen receptor messenger RNA (mRNA) and protein, thus affecting the ability of androgens to control prostate function. AR-positive human prostate cancer cells, LNCaP, were incubated with either the calcium ionophore A23187 or the intracellular endoplasmic reticulum $\mathrm{Ca}^{2+}$ ATPase inhibitor thapsigargin. Subsequently, AR mRNA and protein levels were assessed by Northern and Western blot analysis. Both A23187 and thapsigargin were found to down-regulate steady state AR mRNA levels in a time- and dose-dependent manner. AR mRNA began to decrease after $6-8 \mathrm{~h}$ of incubation with $10^{-6} \mathrm{M}$ A23187 or $10^{-7} \mathrm{M}$ thapsigargin, reaching a nadir at 16 and $10 \mathrm{~h}$ of incubation, respectively. In contrast, control mRNA (glyceraldehyde 3-phosphate
\end{abstract}

dehydrogenase) did not change significantly during the treatments with either A23187 or thapsigargin. AR protein levels were found to be decreased after $12 \mathrm{~h}$ of incubation with either $10^{-6} \mathrm{M} \mathrm{A23187}$ or $10^{-7} \mathrm{M}$ thapsigargin. The decrease in AR mRNA and protein seemed to precede apoptosis, since neither A23187 (24 h) nor thapsigargin (30 h) was found to alter cell morphology within the treatment time. Cycloheximide and actinomycin $D$ were unable to change the calciummediated decrease in AR mRNA, ruling out the necessity for de novo protein synthesis or a change in mRNA stability. Moreover, the decrease in AR mRNA induced by calcium does not seem to involve protein kinase C-or calmodulin-dependent pathways, since inhibitors of these cellular components had no effect. Nuclear run-on assays demonstrated little or no effects of either A23187 or thapsigargin treatment on $\mathrm{AR}$ gene transcription $(8 \mathrm{~h}$ and $10 \mathrm{~h})$. In conclusion, these studies show that intracellular calcium seems to be a potent regulator of AR gene expression in LNCaP cells. (Endocrinology 136: $2172-2178,1995)$
$\mathrm{T}^{\mathrm{H}}$ HE androgen receptor (AR) belongs to the steroid and thyroid hormone receptor superfamily (1). It mediates the effects of testosterone and dihydrotestosterone on growth and differentiation of male urogenital organs (2). Factors that can modulate the expression of AR may play an integral role in these androgen-dependent processes (3).

It has been shown that several hormones and growth factors can regulate the expression of AR. In human cell lines and animal models, androgens can autoregulate the expression of AR $(4,5)$. For example, it has been shown that androgens decrease AR messenger RNA (mRNA) and protein levels in the rat prostate and several human cell lines (4-7). Conversely, it has been reported that AR mRNA and protein levels are increased by the administration of androgens in the rat and mouse prostate, as well as in human genital skin fibroblasts (8-10). More recently, Krongrad et al. (11) have

Received October 3, 1994.

Address all correspondence and requests for reprints to: Dr. Donald J. Tindall, Department of Urology Research, Mayo Clinic and Foundation, 200 First Street SW, Rochester, Minnesota 55905.

* This research was supported in part by NIH Grants CA-58225, DK-47592, and HD-09140.

+ Recipient of a fellowship from the Medical Research Council of Canada. Current address: MS 783, Department of Internal Medicine, Health Science Center, The University of Manitoba, 820 Sherbrook Street, Winnipeg, Manitoba, Canada R3A 1R9.

$\ddagger$ Current address: Department of Endocrinology and Reproduction, Erasmus University Rotterdam, P.O. Box 1738, 3000 DR Rotterdam, The Netherlands.

§ Current address: LRDT-E401 NIEHS, P.O. Box 12233, Research Triangle Park, Chapel Hill, NC 27709. shown that androgen down-regulation of AR mRNA is associated with a transient up-regulation of AR protein in LNCaP cells. It is not clear which intracellular mechanism mediates this autoregulation process, although transcriptional down-regulation of AR by androgens in LNCaP cells has been reported recently $(12,13)$.

At least three distinct second messenger pathways exist within the cell: 1) the protein kinase A (PKA)-dependent pathway; 2) the PKC-dependent pathway; and 3) the calcium-calmodulin kinase-dependent pathway. All three pathways have been implicated in the regulation of the AR. For example, FSH, which activates the PKA pathway, can stimulate the expression of AR mRNA and protein in the rat Sertoli cell (14) (characterization of the mouse AR and human AR (hAR) 5'-flanking regions indicated that sequences contained within the $5^{\prime}$-flanking region can mediate some of the effects of the PKA pathway on AR expression; 15, 16); epidermal growth factor, which activates the PKC pathway, can decrease AR mRNA levels in the human prostate cancer cell line LNCaP (17); and calcitonin, which alters $\mathrm{Ca}^{+2}$ homeostasis, increases AR protein levels in rat Leydig cells (18).

The withdrawal of androgens from the prostate results in massive programmed cell death. It has been indicated that calcium ion influx into the cells may play a role in the pathway leading to androgen-induced apoptosis (19). Moreover, Martikainen and Issacs (20) has shown that in a rat ventral prostate organ culture system, an elevation of intracellular calcium in the presence of normal androgen levels could increase apoptosis to a similar level as caused by androgen 
ablation. Given these data, it seemed worthwhile to investigate whether increased intracellular calcium levels would affect AR mRNA and protein levels, and thereby affect the ability of androgens to control prostate function. Therefore, we have examined the role of calcium in the regulation of AR mRNA and protein expression in the human prostate cancer cell line LNCaP, using Northern and Western blotting analyses.

\section{Materials and Methods}

\section{Materials and cell culture}

A23187, thapsigargin, staurosporine, and trifluoperazine were dissolved in dimethyl sulfoxide (DMSO). Cycloheximide and actinomycin $D$ were dissolved in water. All were purchased from Sigma Chemical Co. (St Louis, MO), except A23187, which was a gift from Dr. C. Y.-F Young (Mayo Clinic). The synthetic androgen mibolerone (Upjohn, Kalamazoo, MI) was dissolved in ethanol. The final concentration of DMSO or ethanol in the culture medium was $0.1 \%$. RPMI 1640 culture medium was purchased from CELOX Co. (Hopkins, MN). Trypsin-EDI'A, antibiotics, and fungizone were purchased from GIBCO (Gaithersburg, MD).

The human prostate cancer cell LNCaP (21) was obtained from the American Type Culture Collection (Rockville, MD). LNCaP cells (30-60 passages) were maintained in RPMI 1640 as a monolayer in the presence of $5 \%$ fetal calf serum (FCS) and $2 \mathrm{~mm}$ glutamine. The medium was changed every 3-4 days. Cells used in the experiment were first grown to $70-80 \%$ confluence in 5\% FCS RPMI 1640, then cultured in serum-free media for $24 \mathrm{~h}$, after which the medium was replaced by $1 \%$ charcoalstripped FCS RPMI 1640 with added hormones. For the actinomycin D experiment, cells were incubated for $8 \mathrm{~h}$ with DMSO or thapsigargin before incubating in fresh medium for the indicated period with $5 \mu \mathrm{g} / \mathrm{ml}$ actinomycin D.

\section{3-(4, 5-Dimethylthiazole-2-yl)-2,5-diphenyltetrazolium bromide (MTT) assay}

To assess the growth rate of cells, a modification of the MTT assay was used (22). Cells were trypsinized, resuspended in RPMI 1640 medium with $1 \%$ charcoal-stripped FCS, and $0.1-\mathrm{ml}$ aliquots $(10,000$ cells) were plated into 96-well plates and cultured for 2 days. Aliquots of culture medium containing the calcium ionophore or thapsigargin $(50 \mu \mathrm{l})$ were added to reach the final concentrations indicated in the experiment. At the end of the incubation period, the medium was carefully removed by inverting the plates on a paper towel, and $50 \mu \mathrm{l}$ of a $0.5 \mathrm{mg} / \mathrm{ml}$ solution of MTT in culture medium with $1 \%$ charcoal-stripped FCS was added. After $4 \mathrm{~h}$ of incubation with MTT at 37 C, $0.15 \mathrm{ml}$ DMSO was added to each well. The plates were placed on a shaker for $5 \mathrm{~min}$, and the absorbance at $550 \mathrm{~nm}$ was read using a multiwell plate reader (SLT Lab Instruments, model EAR $400 \mathrm{AT}$ ). Six wells were used for each test point. Wells containing medium, but no cells, served as blank controls.

\section{$R N A$ extraction and Northern blot analysis}

Total RNA was obtained by lysing the cells in $\mathrm{LiCl}(3 \mathrm{M})$ and urea (6 M) (23). Samples were homogenized on ice for $1 \mathrm{~min}$ at 24,000 rpm with a Tissuemizer (Kunkel, Staufen, Germany) and incubated at $-20 \mathrm{C}$ for $30 \mathrm{~min}$. Samples were centrifuged for $20 \mathrm{~min}$ at $80,000 \times \mathrm{g}$. Pellets were resuspended in ES solution [0.1\% sodium dodecyl sulfate (SDS) and 0.2 $\mathrm{mm}$ EDTA], extracted once with phenol/chloroform/isoamyl alcohol and once with chloroform/isoamyl alcohol, and precipitated with a 1:9 vol of $3 \mathrm{~m}$ sodium acetate ( $\mathrm{pH} 5.2$ ) and $2.5 \mathrm{vol}$ ethanol. The RNA pellet was resuspended in water and was quantified by reading the absorbance at 260 and $280 \mathrm{~nm}$. RNA was separated by electrophoresis on a $1 \%$ agarose gel, which contained $2 \%$ formaldehyde, using $1 \times$ MOPS buffer (20 mM 3- $N$-morpholino propansulfonic acid, pH 7.0, $5 \mathrm{~mm}$ sodium acetate, and $1 \mathrm{mM}$ EDTA). The RNA was transferred to a Hybond-N or Hybond-N+ membrane (Amersham, Arlington Heights, IL) and was
UV cross-linked to the membrane using a stratalinker (Stratagene, San Diego, CA).

The hAR probe for Northern analysis [542-base pair pvuII-pvuII complementary DNA (cDNA) fragment] was generated by digesting the full-length hAR cDNA (24) with pvuII. The housekeeping enzyme glyceraldehyde 3-phosphate dehydrogenase (GAPDH; 740-base pair pstIpstI cDNA fragment) was generated by cutting the plasmid, which contained GAPDH, with $p$ stI. The cDNA was labeled with $\left[\alpha^{32} P\right]$ deoxyATP using a random-primed labeling kit (Boehringer Mannheim, Indianapolis, IN). The reaction was incubated at $22 \mathrm{C}$ for $1 \mathrm{~h}$, and the labeled cDNA probe was separated from free nucleotides by passage through Sephadex G-50 packed in a 5-ml pipette and added directly into the hybridization buffer [ $50 \%$ formamide, $0.5 \%$ SDS, $6 \times$ SSC $(1 \times$ SSC $=150$ mM sodium chloride and $15 \mathrm{~mm}$ sodium citrate), $5 \times$ Denhardt's solution, $10 \mathrm{~mm}$ phosphate buffer, and $100 \mu \mathrm{g} / \mathrm{ml}$ salmon sperm $D N A]$

Northern blots were prehybridized for $1 \mathrm{~h}$ at $42 \mathrm{C}$ and then hybridized with labeled probes overnight at $42 \mathrm{C}$. Blots were washed twice in $2 \times$ SSC and $0.1 \%$ SDS at room temperature for $15 \mathrm{~min}$ and once in $0.1 \times$ SSC and $0.1 \%$ SDS at $65 \mathrm{C}$ for $15 \mathrm{~min}$, quantified with a PhosphorImager 425 (Molecular Dynamics, Sunnyvale, CA), and exposed to x-ray film.

\section{Immunoblotting}

Cellular proteins were isolated by homogenizing the cells in $10 \mathrm{~mm}$ Tris- $\mathrm{HCl}, \mathrm{pH} 7.5,1 \mathrm{~mm}$ EDTA, pH 8.0, $10 \mathrm{~mm} \mathrm{MgCl}_{2}, 1 \%$ SDS, $0.25 \mathrm{~m}$ sucrose, $5 \mu \mathrm{g} / \mathrm{ml}$ leupeptin, $1 \mathrm{~mm}$ phenylmethylsulfonyl fluoride, and $5 \mu \mathrm{g} / \mathrm{ml}$ bacitracin for five strokes. The lysates were dialyzed against water overnight, lyophilized, and reconstituted in water. Equal amounts of protein $(10 \mu \mathrm{g} /$ lane) were passed through a $10 \%$ precast gel (NOVEX, San Diego, CA) at $150 \mathrm{~V}$ for $2 \mathrm{~h}$ at $4 \mathrm{C}$. Resolved proteins were transferred electrophoretically to nitrocellulose (Bio-Rad, Hercules, CA) at $4 \mathrm{C}$ for $3 \mathrm{~h}$ at $30 \mathrm{~mA}$ in a buffer containing $25 \mathrm{~mm}$ glycine, $192 \mathrm{~mm}$ Tris, and $10 \%$ methanol. Nonspecific binding of the antibodies to the membranes was diminished by preincubating the blots in TBS $(50 \mathrm{~mm}$ Tris- $\mathrm{HCl}$ and 150 $\mathrm{mm} \mathrm{NaCl}, \mathrm{pH} 7.4$ ) in the presence of $3 \%$ dry milk for $1 \mathrm{~h}$ at room temperature. Blots were incubated with rabbit anti-AR antibody $(0.5$ $\mu \mathrm{g} / \mathrm{ml}$ PG-21, kindly provided by Dr. Gail Prins, Inniversity of Illinois School of Medicine, Chicago, IL) (25) in the presence or absence of a 10-fold molar excess of AR21 peptide $(0.1 \mu \mathrm{g} / \mathrm{ml})$ in TBS containing $1 \%$ dry milk and $0.2 \%$ Tween-20 (Bio-Rad) at $4 \mathrm{C}$ for $24 \quad 48 \mathrm{~h}$ and then with a peroxidase-labeled antirabbit antibody (1:1000 dilution; Amersham) in the same buffer at room temperature for $1 \mathrm{~h}$. After each incubation, blots were washed twice with TBS containing $0.2 \%$ Tween- 20 for $10 \mathrm{~min}$. Immunoreactive bands were visualized using an enhanced chemiluminescence kit (Amersham).

\section{Nuclear run-on}

The nuclear run-on assay was performed as described by Blok et al. (14). Cloned cDNAs ( $5 \mu \mathrm{g} / \mathrm{slot})$ used to detect the mRNA transcription rate of AR and GAPDH genes were: Bluescript II SK \pm (Stratagene, La Jolla, CA) linearized with EcoRI as a background control, pBlueAR (26) linearized with HindIII for AR, and pGAPDH (Clontech, Palo Alto, CA) linearized with PstI for GAPDH. Culture conditions were as described previously; the time points at which the cells were harvested for nuclei isolation for the transcription elongation reaction were 8 and $10 \mathrm{~h}$ after A23187 or thapsigargin was administered to the LNCaP cells. Hybridization was performed at $65 \mathrm{C}$ for $72 \mathrm{~h}$; washing of the blots was performed in $1 \times$ SSC and $0.5 \%$ SDS at $55 \mathrm{C}$ for $30 \mathrm{~min}$. The film was exposed for $72 \mathrm{~h}$.

\section{Results}

To determine whether intracellular levels of calcium affected the expression of the AR, the AR-containing cell line $\mathrm{LNCaP}$ was treated with the calcium ionophores $\mathrm{A} 23187$ $\left(10^{-6} \mathrm{M}\right)$ or ionomycin $\left(10^{-6} \mathrm{M}\right)$, or the intracellular $\mathrm{Ca}^{2+}$. ATPase inhibitor thapsigargin $\left(10^{-7} \mathrm{M}\right)$, for $16 \mathrm{~h}$. RNA was analyzed on Northern blots incubated with an hAR cDNA probe. Three major AR mRNAs of 11,8, and 4.7 kilobases 
were detected (Fig. 1), which were of similar sizes to those reported previously for AR mRNA in LNCaP cells (27). The expression of all three AR transcripts decreased after treatment with A23187, ionomycin, or thapsigargin.

The time dependencies of A23187 and thapsigargin downregulation of $\mathrm{AR}$ were examined next. Levels of AR transcripts in LNCaP cells began to decrease after $6-8 \mathrm{~h}$ of incubation with A23187 $\left(10^{-6} \mathrm{M}\right)$, reached a nadir after $16 \mathrm{~h}$ of incubation ( $29 \%$ of control), and increased to $59 \%$ of the control level at $24 \mathrm{~h}$ (Fig. 2). Thapsigargin $\left(10^{-7} \mathrm{M}\right)$ treatment also resulted in a reduction in AR transcripts, decreasing after $6-8 \mathrm{~h}$ of incubation, reaching $23 \%$ of the control level after $10 \mathrm{~h}$, and increasing to $68 \%$ of control by $24 \mathrm{~h}$ (Fig. 2).

Next, the dose response of AR mRNA to A23187 and thapsigargin was examined. An 8-h treatment with thapsigargin reduced AR mRNA levels at doses as low as $50 \mathrm{nM}$, whereas higher concentrations of A23187 (about $500 \mathrm{nM}$ ) were required to reduce AR mRNA levels (Fig. 3). These doses are similar to those reported previously for biological effects of these compounds (28). Next, AR protein levels were examined. As shown in Fig. 4, $10^{-6} \mathrm{M}$ A23187 and $10^{-7} \mathrm{M}$

\section{LNCaP cells}

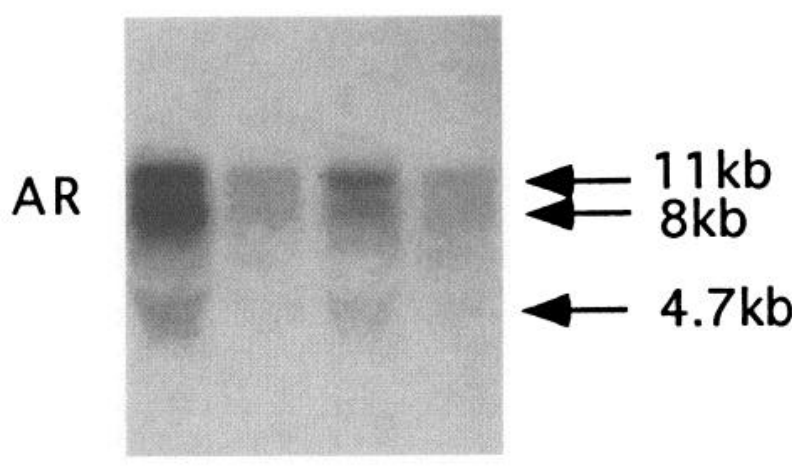

\section{GAPDH}
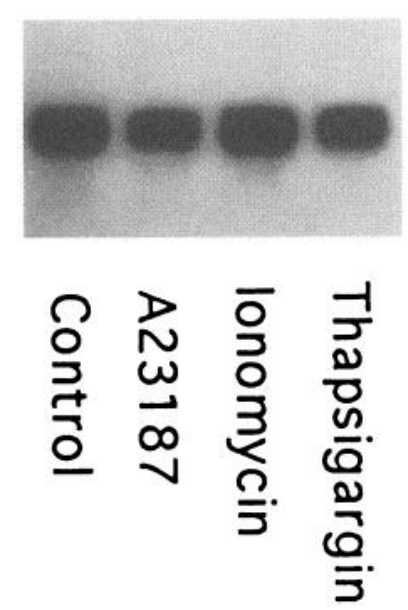

FIG. 1. Calcium regulation of AR mRNA levels in human prostate cancer $\mathrm{LNCaP}$ cells. LNCaP cells were treated with $10^{-6} \mathrm{M}$ A23187, $10^{-6} \mathrm{M}$ ionomycin, or $10^{-7} \mathrm{M}$ thapsigargin for $16 \mathrm{~h}$. Total RNA was extracted and analyzed on Northern blots ( $20 \mu \mathrm{g} / \mathrm{gane})$, which were hybridized with an hAR pvuII-pvuII cDNA probe. The filter was rehybridized with a housekeeping enzyme GAPDH cDNA probe to verify equal loading. AR transcripts are indicated by the arrows.

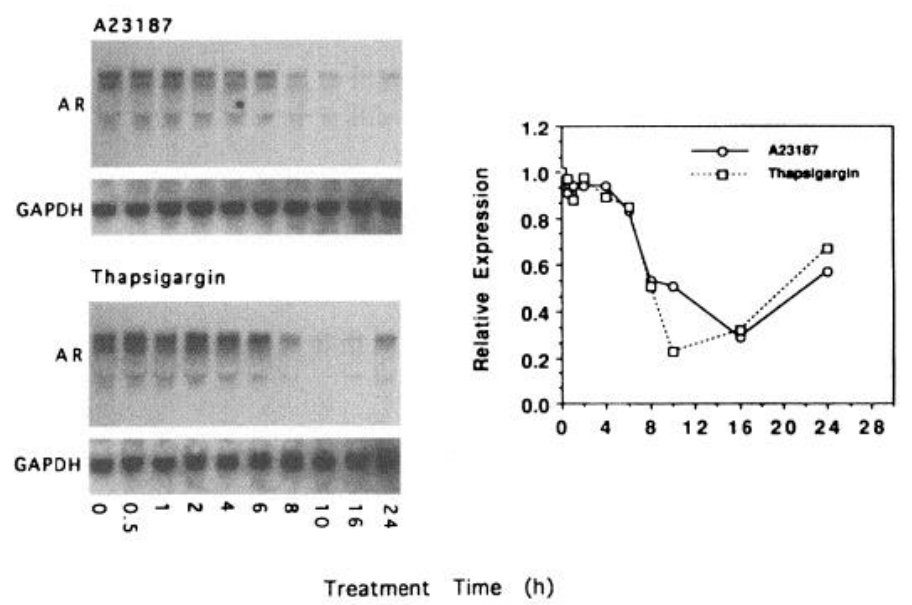

FIG. 2. Time course of calcium ionophore A23187 and thapsigargin regulation of $\mathrm{AR}$ mRNA in $\mathrm{LNCaP}$ cells. $\mathrm{LNCaP}$ cells were treated with $10^{-6} \mathrm{M} \mathrm{A23187}$ or $10^{-7} \mathrm{M}$ thapsigargin for various periods of time $(0-24 \mathrm{~h})$. Total RNA was extracted and analyzed on Northern blots $(20 \mu \mathrm{g} /$ lane $)$ with an hAR cDNA probe. The filter was rehybridized with GAPDH cDNA to correct for variations in the loading of RNA. The graph represents the mean of two independent experiments.

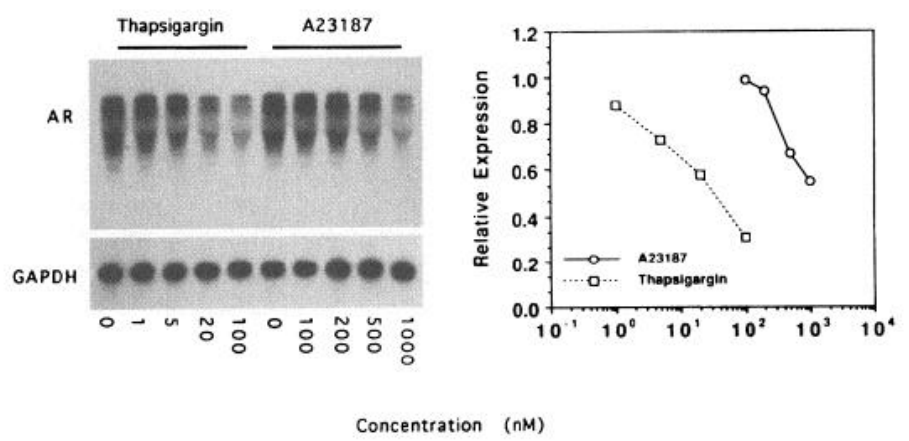

FIG. 3. Dose dependency of calcium ionophore A23187 and thapsigargin regulation of $\mathrm{AR}$ mRNA in $\mathrm{LNCaP}$ cells. $\mathrm{LNCaP}$ cells were treated with A23187 (100-1000 nM) or thapsigargin (1-100 nM) for 8 h. Total RNA was extracted and analyzed on Northern blots (20 $\mu \mathrm{g} /$ lane) with an hAR cDNA probe. The filter was rehybridized with GAPDH cDNA. The graph represents the mean of two independent experiments.

thapsigargin effectively reduced AR protein levels after $12 \mathrm{~h}$ of incubation. However, at $24 \mathrm{~h}$ of incubation with either compound, the AR protein levels had almost returned to control levels.

Calcium has been reported to induce apoptosis in prostate epithelial cells $(19,20)$. To determine whether the observed effects on the AR were the result of apoptosis, LNCaP cells were incubated with different concentrations of A23187 or thapsigargin for various lengths of time (Fig. 5). At the end of the experiments, no morphological differences were observed between control cells incubated with DMSO or cells treated with A23187 or thapsigargin (data not shown). Furthermore, A23187 had no effect on the growth rate of the $\mathrm{LNCaP}$ cells as measured by the MTT assay, indicating the viability of the cells. In the presence of thapsigargin, however, LNCaP cells became arrested in growth (Fig. 5). The first morphological indications for apoptosis were observed after $36 \mathrm{~h}$ of culture in the presence of A23187 and $12 \mathrm{~h}$ later for thapsigargin ( $48 \mathrm{~h}$; data not shown). These results suggest 


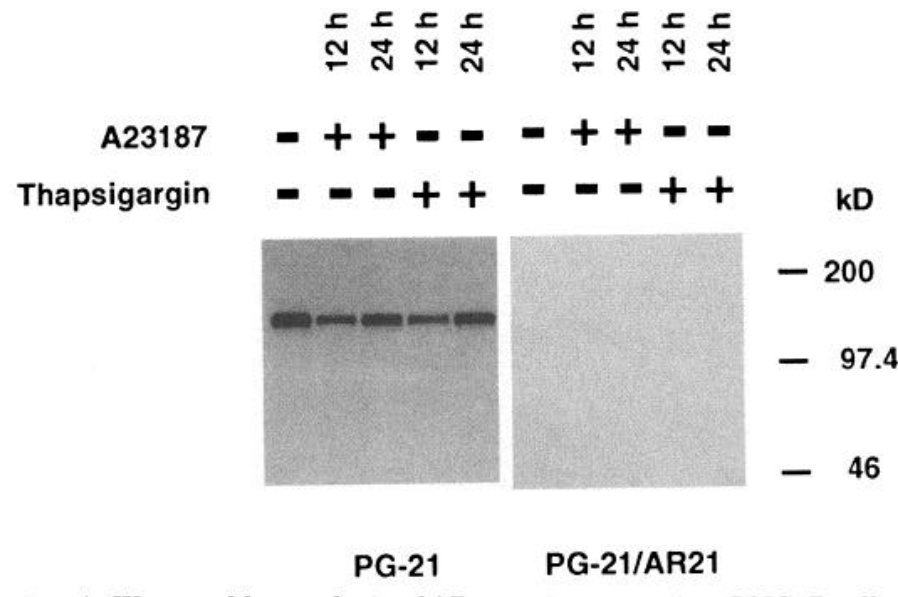

FIG. 4. Western blot analysis of AR protein expression. LNCaP cells were treated with $10^{-6} \mathrm{M} A 23187$ or $10^{-7} \mathrm{M}$ thapsigargin for 12 and $24 \mathrm{~h}$. Total cellular proteins were isolated and separated by SDS polyacrylamide gel electrophoresis. Immunological detection was performed using the PG-21 antibody either in the absence (left panel) or presence (right panel) of the AR21 peptide as described in Materials and Methods. The positions of the molecular mass markers (in kilodaltons) are shown on the right. The major immunoreactive band is at 110 kilodaltons. This experiment was repeated twice.

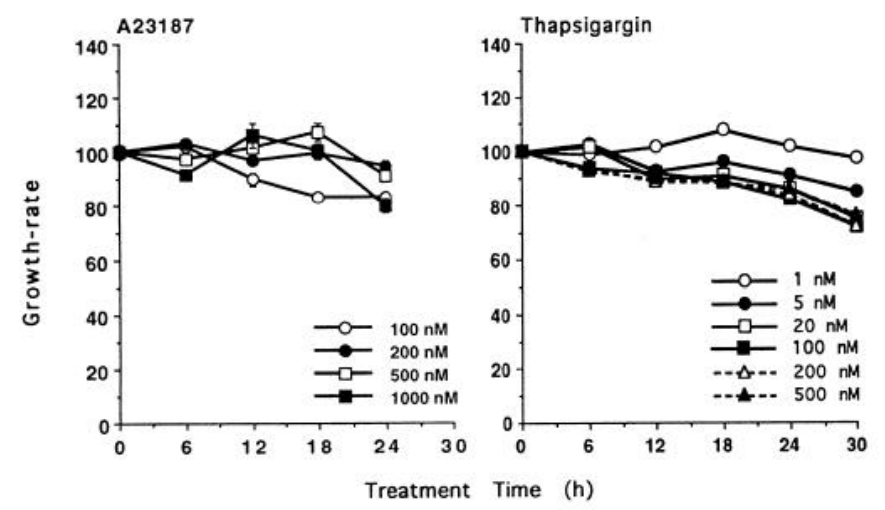

FIG. 5. Calcium ionophore A23187 and thapsigargin regulation of LNCaP cell growth rate. $\mathrm{LNCaP}$ cells were treated with vehicle (DMSO) alone or various concentrations of A23187 and thapsigargin for the different periods of time. At the end of treatment, cells were incubated with $0.5 \mathrm{mg} / \mathrm{ml}$ MTT for $4 \mathrm{~h}$. Cells were lysed in DMSO, and $550 \mathrm{~nm}$ absorbance was measured by a multiwell plate reader. Viable cells at each dose are expressed as the percentage of control at that time (mean \pm SEM, $n=6$; for thapsigargin the SEM was less than $3 \%$ and, consequently, could not be depicted in the graph). This experiment was repeated twice.

that calcium-induced apoptosis is preceded by a downregulation of AR mRNA levels in LNCaP cells.

To explore the mechanism of calcium regulation of $A R$ mRNA expression in LNCaP cells, we measured the effects of various inhibitors on the regulatory pathways in LNCaP cells. The dosages of these drugs and the time frames of the experiments were based on our previous experiences using endometrial carcinoma cell lines (29). The 30-min pretreatment of the cells with either cycloheximide, staurosporine, or trifluoperazine was performed to allow these compounds to exert their actions before intracellular calcium became increased. Cycloheximide was used to inhibit protein synthesis (30); staurosporine was used to inhibit PKC (31); and triflu- operazine was used to inhibit calmodulin (32). None of these inhibitors affected the AR mRNA levels, nor did they prevent the calcium down-regulation of AR mRNA levels (Fig. 6). The lack of effect of staurosporine and trifluoperazine suggests that a pathway other than PKC or calmodulin might be involved.

Since cycloheximide had no effect, de novo protein synthesis did not seem to be involved in the calcium effects on AR mRNA expression. Thus, the effect of calcium might be due to a posttranscriptional change in the half-life of the message. Therefore, we measured the effects of thapsigargin on AR mRNA half-life. LNCaP cells were incubated with DMSO or thapsigargin for $8 \mathrm{~h}$ and then treated with the RNA synthesis inhibitor actinomycin D $(5 \mu \mathrm{g} / \mathrm{ml})$ for different periods of time (0-24 h). As shown in Fig. 7, the half-life of the AR mRNA in DMSO-treated LNCaP cells was $7.5 \mathrm{~h}$. For thapsigargin-treated LNCaP cells, the half-life of AR mRNA was $8.1 \mathrm{~h}$. This experiment showed that an accelerated turnover of AR mRNA in the presence of thapsigargin was not detectable in LNCaP cells, suggesting that a posttranscriptional mechanism of calcium down-regulation of AR mRNA in LNCaP cells was unlikely.

We next asked whether transcription of the AR gene was affected by A23187 or thapsigargin. Transcription of the AR gene in LNCaP cells, cultured in the presence of A23187 or thapsigargin, was measured using a nuclear run-on assay. As shown in Fig. 8, transcription of both the AR gene and the

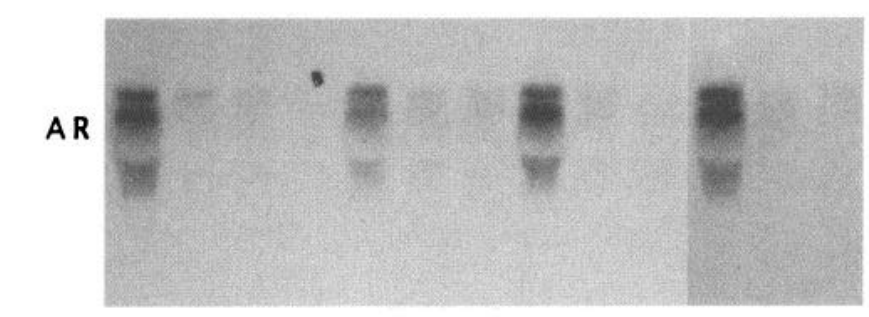

GAPDH

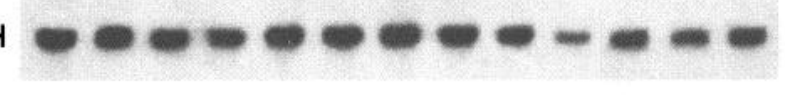

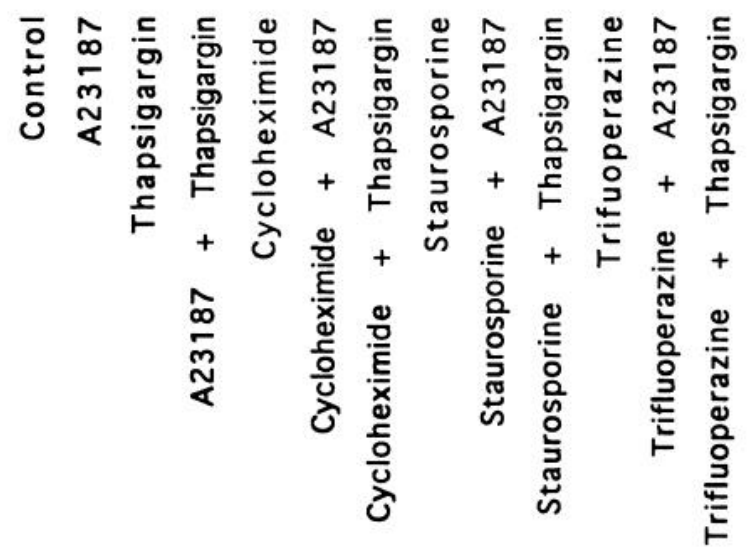

FiG. 6. Cycloheximide, staurosporine, and trifluoperazine effects on calcium ionophore A23187 and thapsigargin down-regulation of AR mRNA in LNCaP cells. $\mathrm{LNCaP}$ cells were treated with cycloheximide $(10 \mu \mathrm{g} / \mathrm{ml})$, staurosporine $\left(10^{-8} \mathrm{M}\right)$, or trifluoperazine $\left(10^{-6} \mathrm{M}\right)$ for 30 min before adding A23187 $\left(10^{-6} \mathrm{M}\right)$ or thapsigargin $\left(10^{-7} \mathrm{M}\right)$. Cells were incubated with A23187 or thapsigargin for $8 \mathrm{~h}$. Total RNA was isolated and subjected to Northern blot analysis with hAR and GAPDH cDNA probes. This experiment was repeated twice. 


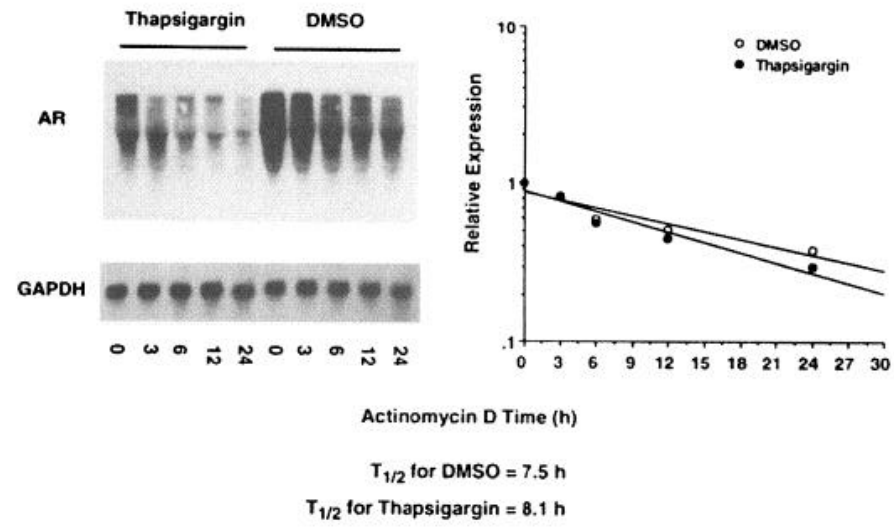

FIG. 7. Thapsigargin regulation of the AR mRNA half-life in LNCaP cells. $\mathrm{LNCaP}$ cells were treated with vehicle (DMSO) alone or thapsigargin $\left(10^{-7} \mathrm{M}\right)$ for $8 \mathrm{~h}$ and then incubated with actinomycin $\mathrm{D}(5$ $\mu \mathrm{g} / \mathrm{ml}$ ) for the indicated time. Total RNA was isolated and subjected to Northern blot analysis with $\mathrm{hAR}$ and GAPDH $\mathrm{cDNA}$ probes. The half-life of AR mRNA under each treatment was calculated by a regression analysis of the slopes of the line. The graph represents the mean of three independent experiments.

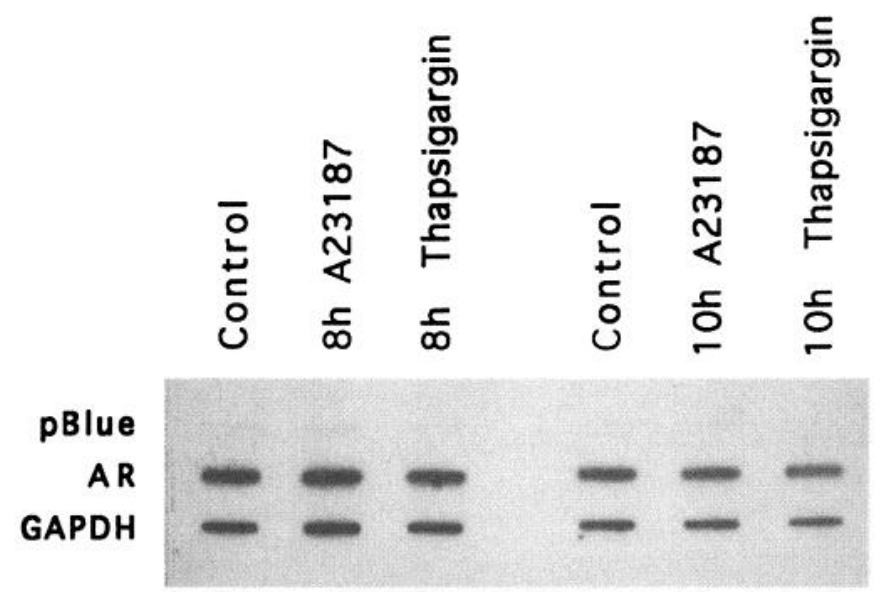

Fig. 8. Nuclear run-on. LNCaP cells were treated with $10^{-6} \mathrm{M}$ A23187 or $10^{-7} \mathrm{M}$ thapsigargin for 8 or $10 \mathrm{~h}$, respectively. Transcription elongation was allowed to continue for $30 \mathrm{~min}$ before total RNA was isolated from the nuclei of control and treated cells. The radioactively labeled RNAs were hybridized to: pBlue, background control vector; $A R$, mouse AR cDNA; and GAPDH, which serves to correct for variations in the loading of labeled RNA. This experiment was repeated twice.

GAPDH gene could be measured. However, no inhibition of AR gene transcription in LNCaP cells after 8 or $10 \mathrm{~h}$ of incubation in the presence of either A23187 or thapsigargin was observed, indicating that AR gene transcription is not affected by either A23187 or thapsigargin treatments. However, it is possible that the effects of both drugs on AR gene transcription were weak and consequently not detected using a nuclear run-on assay (12).

\section{Discussion}

The prostate is dependent on circulating concentrations of androgens and the presence of androgen receptors for normal growth, differentiation, and maintenance of differentiated functions $(2,3)$. Thus, factors that regulate expression of the AR presumably regulate the ability of androgens to control prostate function. For example, it has been demonstrated that retinoic acid can down-regulate both AR protein levels and androgenic induction of prostate-specific androgen and hK2 mRNAs in LNCaP cells (33).

The studies reported in this paper demonstrated that calcium can also modulate the expression of AR protein and mRNA in LNCaP cells. Thus, two distinct pathways, calcium and retinoic acid, are able to regulate $A R$ expression and consequently androgen effects in the prostate.

In the current study two compounds, A23187 and thapsigargin, were used to increase intracellular calcium levels in LNCaP cells. A23187 is a Ca ${ }^{2+}$ ionophore, widely used to analyze the role of $\mathrm{Ca}^{2+}$ in the regulation of gene expression (34-36). However, several disadvantages in the use of A23187 have been reported; A23187 has pleiotropic effects $(34,36)$, and A23187 administration sometimes gives rise to a mixed $\mathrm{Ca}^{2+}$ and cAMP signal $(35,36)$. Therefore, we also used the specific endoplasmic reticulum $\mathrm{Ca}^{2+}$-ATPase inhibitor thapsigargin. Its effects are reported to be highly specific by initiating only one event: a rapid increase in cytosolic free $\mathrm{Ca}^{2+}$. Thapsigargin has been reported to be a potent tumor promoter, inducing growth- and transformation-related genes in NIH3T3 cells (36). Its role in $\mathrm{LNCaP}$ cells, however, seems to be directly opposite of these observations, as will be described below.

Since calcium has been reported to mediate apoptosis in the rat ventral prostate $(19,20)$, we tested the possibility of whether the down-regulation of AR by calcium could be due to the initiation of apoptosis. In our experiments, the calcium ionophore A23187 had no effect on cell growth or morphology, indicating that these cells were viable within the experimental setup. Thapsigargin treatment of the $\mathrm{LNCaP}$ cells, however, caused growth arrest. We do not think apoptosis is involved in thapsigargin-induced growth arrest, because the morphology of the cells remained unchanged during the 30-h incubation period (the first morphological changes were observed after $48 \mathrm{~h}$; cells were rounding up and $24 \mathrm{~h}$ later were detaching from the plastic). Also, it has been demonstrated previously that cycloheximide can prevent calcium-induced apoptosis (37), suggesting that calciuminduced apoptosis of prostate cells requires new protein synthesis. However, in our studies, cycloheximide did not reverse the calcium effect on AR gene expression. Finally, expression of the housekeeping enzyme GAPDH was stable during treatment with either the calcium ionophore or thapsigargin. Our data suggest that the effect of calcium on AR mRNA occurs before apoptotic activation in LNCaP cells.

Several studies have shown that the calcium ionophore A23187 and thapsigargin can selectively activate gene expression $(36,38)$ or inactivate gene expression via increasing intracellular calcium levels $(28,39,40)$. Recently, calciumactivated cis-acting elements have been found in the 5 '-flanking region of a glucose- and calcium-regulated grp 78 gene $(41,42)$. The sequence of this element is distinct from the cAMP response element, which mediates A23187 activation of the c-fos promoter (43), and from tetradecanoylphorbol acetate- and serum-responsive elements that have been shown to mediate thapsigargin activation of the c-jun and c-fos promoters (36). Interestingly, sequences within the hAR 
5'-flanking region show strong homology to the A23178induced elements of the grp 78 gene. Although nuclear run-on experiments showed no effect on the regulation of AR gene transcription by $\mathrm{A} 23187$ or thapsigargin treatment, it is possible that this assay is not sensitive enough to pick up relatively small differences in the gene transcription rate (12); therefore, transcriptional regulation of AR mRNA cannot be ruled out.

Calcium effects on gene expression are usually dependent on a rapid phosphorylation mechanism mediated by calmodulin or other calcium-regulated kinases. Calcium normally induces rapid expression of many genes such as c-jun and c-fos. However, inhibition of gene expression by calcium usually occurs with a pattern of relatively slow kinetics (39, 41). Calcium inhibition of the AR gene occurred after $6 \mathrm{~h}$ of incubation with A23187 and thapsigargin. This would argue against trans-activation of AR via a rapid phosphorylation mechanism. The inability of staurosporine, a PKC inhibitor (31), and trifluoperazine, a calmodulin inhibitor (32), to reverse the calcium inhibition of $A R$ gene expression also supports the argument that calcium down-regulation of AR gene expression occurs by a mechanism other than phosphorylation.

In conclusion, increases in intracellular calcium concentration by the calcium ionophore or thapsigargin effectively reduce AR expression in INC.AP cells. Calcium inhibition of AR expression seems to precede calcium-induced apoptotic cell death. Furthermore, the mechanism of this reduction seems to be different from a pathway in which the calcium signal is transduced via a phosphorylation mechanism.

\section{Acknowledgments}

We would like to acknowledge Ms. Marceil Blexrud for her excellent technical assistance and Ms. Kelli Ambroson for her assistance in the preparation of this manuscript.

\section{References}

1. Evans RM 1988 The steroid and thyroid hormone receptor superfamily. Science $240: 889-895$

2. Cunha GR, Alarid ET, Turner T, Donjacour AA, Boutin EL, Foster BA 1992 Normal and abnormal development of the male urogenital tract. Role of androgens, mesenchymal-epithelial interactions, and growth factors. J Androl 13:465-475

3. Lindzey JK, Kumar MV, Grossmann ME, Young CY-F, Tindall DJ 1994 Molecular mechanisms of androgen action. In: Litwack G (ed) Vitamins and Hormones. Academic Press Inc., San Diego, vol 49: 383-418

4. Quarmby VE, Yarbrough WG, Lubahn DB, French FS, Wilson EM 1990 Autologous down-regulation of androgen receptor messenger ribonucleic acid. Mol Endocrinol 4:22-28

5. Shan LX, Rodriguez MC, Janne OA 1990 Regulation of androgen receptor protein and mRNA concentrations by androgens in rat ventral prostate and seminal vesicles and in human hepatoma cells. Mol Endocrinol 4:1636-1646

6. Trapman J, Ris-Stalpers C, van der Korput JA, Kuiper GG, Faber PW 1990 The androgen receptor: functional structure and expression in transplanted human prostate tumors and prostate tumor cell lines. J Steroid Biochem Mol Biol 37:837-842

7. Hackenberg R, Hawighorst T, Filmer A, Slater EP, Bock K, Beato M 1992 Regulation of androgen receptor mRNA and protein level by steroid hormones in human mammary cancer cells. J Steroid Biochem Mol Biol 43:599-607
8. Kaufman M, Pinsky L, Feder-Hollander R 1981 Defective up-regulation of the androgen receptor in human androgen insensitivity. Nature 293:735-737

9. Gad YZ, Berkovitz GD, Migeon CJ, Brown TR 1988 Studies of up-regulation of androgen receptors in genital skin fibroblasts. Mol Cell Endocrinol 57:205-213

10. Takeda H, Nakamoto T, Kokontis J, Chodak GW, Chang C 1991 Autoregulation of androgen receptor expression in rodent prostate: immunohistochemical and in situ hybridization analysis. Biochem Biophys Res Commun 177:488-496

11. Krongrad A, Wilson CM, Wilson JD, Allman DR, McPhaul MJ 1991 Androgen increases androgen receptor protein while decreasing receptor mRNA in LNCaP cells. Mol Cell Endocrinol 76:79-88

12. Blok LJ, Themmen AP, Peters AH, Trapman J, Baarends WM, Hoogerbrugge JW, Grootegoed JA 1992 Transcriptional regulation of androgen receptor gene expression in Sertoli cells and other cell types. Mol Cell Endocrinol 88:153-164

13. Wolf DA, Herzinger T, Hermeking I, Blaschke D, Horz W 1993 Transcriptional and posttranscriptional regulation of human androgen receptor expression by androgen. Mol Endocrinol 7:924-936

14. Blok LJ, Hoogerbrugge JW, Themmen AP, Baarends WM, Post M, Grootegoed JA 1992 Transient down-regulation of androgen receptor messenger ribonucleic acid (mRNA) expression in Sertoli cells by follicle-stimulating hormone is followed by up-regulation of androgen receptor mRNA and protein. Endocrinology 131:1343-1349

15. Lindzey JK, Grossmann ME, Kumar MV, Tindall DJ 1993 Regulation of the 5 '-flanking region of the mouse androgen receptor gene by CAMP and androgen. Mol Endocrinol 7:1530-1540

16. Mizokami $\Lambda$, Yeh S-Y, Chang C 1994 Identification of 3',5'-cyclic adenosine monophosphate response element and other cis-acting elements in the human androgen receptor gene promoter. Mol Endocrinol 8:77-88

17. Mizokami A, Saiga H, Matsui T, Mita T, Sugita A 1992 Regulation of androgen receptor by androgen and epidermal growth factor in a human prostatic cancer cell line, LNCaP. Endocrinol Jpn 39:235243

18. Nakhla AM, Bardin CW, Salomon Y, Mather JP, Janne OA 1989 The actions of calcitonin on the TM3 Leydig cell line and on rat Leydig cell-enriched cultures. J Androl 10:311-320

19. Connor J, Sawcruk IS, Benson MC, Tomashefsky P, O'Toole KM, Olsson CA, Buttyan R 1988 Calcium channel antagonists delay regression of androgen-dependent tissues and suppress gene activity associated with cell death. Prostate 13:119-130

20. Martikainen P, Isaacs J 1990 Role of calcium in the programmed death of rat prostatic glandular cells. Prostate 17:175-187

21. Horoszewicz JS, Leong SS, Kawinski E, Karr JP, Rusenthal H, Chu TM, Mirand EA, Murphy GP 1983 LNCaP model of human prostatic carcinoma. Cancer Res 43:1809-1818

22. Carmichael J, DeGraff WG, Gazdar AF, Minna JD, Mitchell JB 1987 Evaluation of a tetrazolium-based semiautomated colorimetric assay: assessment of chemosensitivity testing. Cancer Res 47:936942

23. Auffray C, Rougeon F 1980 Purification of mouse immunoglobulin heavy-chain messenger RNAs from total myeloma tumor RNA. Eur J Biochem 107:303-314

24. Young CY-F, Qiu S, Prescott JL, Tindall DJ 1990 Overexpression of a partial human androgen receptor in $E$. coli: characterization of steroid binding, DNA binding, and immunological properties. Mol Endocrinol 4:1841-1849

25. Prins GS, Birch L, Greene GL 1991 Androgen receptor localization in different cell types of the adult rat prostate. Endocrinology 129: 3187-3199

26. He WW, Fischer LM, Sun S, Bilhartz DL, Zhu X, Young CY-F, Kelley DB, Tindall DJ 1990 Molecular cloning of androgen receptors from divergent species with a polymerase chain reaction technique: complete cDNA sequence of the mouse androgen receptor and isolation of androgen receptor cDNA probes from dog, guinea pig and clawed frog. Biochem Biophys Res Commun 171:697-704

27. Trapman J, Klaassen P, Kuiper GG, van der Korput JA, Faber PW, van Rooij HC, Geurts van Kessel A, Voorhorst MM, Mulder E, Brinkmann AO 1988 Cloning, structure and expression of a cDNA encoding the human androgen receptor. Biochem Biophys Res Commun 153:241-248 
28. Hovis JG, Meyer T, Teasdale RM, Albrecht BN, Yorek MA, Lowe Jr WL 1993 Intracellular calcium regulates insulin-like growth factor-I messenger ribonucleic acid levels. Endocrinology 132: 1931-1938

29. Gong Y, Ballejo G, Alkhalaf B, Molnar P, Murphy LC, Murphy LJ 1992 Phorbol esters differentially regulate the expression of insulinlike growth factor-binding proteins in endometrial carcinoma cells. Endocrinology 131:2747-2754

30. Ranganathan G, Blatti SP, Subramaniam M, Fass DN, Maihle NJ, Getz MJ 1991 Cloning of murine tissue factor and regulation of gene expression by transforming growth factor type $\beta 1$. J Biol Chem 266:496-501

31. Campbell GS, Pang L, Miyasaka T, Saltiel AR, Carter-Su C 1992 Stimulation by growth hormone of MAP kinase activity in 3T3F442A fibroblasts. J Biol Chem 267:6074-6080

32. Jackson AE, Puett D 1986 Binding of trifluoperazine and fluorenecontaining compound to calmodulin and adducts. Biochem Pharmacol 35:4395-4400

33. Young CY-F, Murtha PE, Andrews PE, Lindzey JK, Tindall DJ 1994 Antagonism of androgen action in prostate tumor cells by retinoic acid. Prostate 25:39-45

34. Buscher M, Rahmsdorf HJ, Litfin M, Karin M, Herrlich P 1988 Activation of the c-fos gene by UV and phorbol ester: different signal transduction pathways converge to the same enhancer element. Oncogene 3:301-311

35. Erlij D, Gersten L, Sterba G, Schoen HF 1986 Role of prostaglandin release in the response of tight epithelia to $\mathrm{Ca}^{2+}$ ionophores. Am J Physiol 250:C629-C636

36. Schönthal A, Sugarman J, Brown JH, Hanley MR, Feramisco JR
1991 Regulation of $c$-fos and c-jun proto-oncogene expression by the $\mathrm{Ca}^{2+}$-ATPase inhibitor thapsigargin. Proc Natl Acad Sci USA 88: 7096-7100

37. Sells SF, Wood DP, Joshibarve SS, Muthukumar S, Jacob RJ, Crist SA, Humphreys S, Rangnekar VM 1994 Commonality of the gene programs induced by effectors of apoptosis in androgen-dependent and -independent prostate cells. Cell Growth Differ 5:457-466

38. Resendez Jr E, Attenello JW, Grafsky A, Chang CS, Lee AS 1985 Calcium ionophore A23187 induces expression of glucose-regulated genes and their heterologous fusion genes. Mol Cell Biol 5:1212-1219

39. Saji M, Ikuyama S, Akamizu T, Kohn LD 1991 Increases in cytosolic $\mathrm{Ca}^{2+}$ down regulate thyrotropin receptor gene expression by a mechanism different from the cAMP signal. Biochem Biophys Res Commun 176:94-101

40. Ree AH, Landmark BF, Walaas SI, Lahooti H, Eikvar L, Eskild W, Hansson V 1991 Down-regulation of messenger ribonucleic acid and protein levels for estrogen receptors by phorbol ester and calcium in MCF-7 cells. Endocrinology 129:339-344

41. Lin AY, Chang SC, Lee AS 1986 A calcium ionophore-inducible cellular promoter is highly active and has enhancer-like properties. Mol Cell Biol 6:1235-1243

42. Li WW, Alexandre S, Cao X, Lee AS 1993 Transactivation of the grp78 promoter by $\mathrm{Ca}^{2+}$ depletion. A comparative analysis with A23187 and the endoplasmic reticulum $\left.\mathrm{Ca}^{2+}\right)$-ATPase inhibitor thapsigargin. J Biol Chem 268:12003-12009

43. Sheng M, Dougan ST, McFadden G, Greenberg ME 1988 Calcium and growth factor pathways of c-fos transcriptional activation require distinct upstream regulatory sequences. Mol Cell Biol 8:2787-2796 